\title{
Keterampilan Guru PAK Untuk Meningkatkan Minat Belajar Murid Dalam Proses Pembelajaran Di Kelas
}

\author{
Dwiati Yulianingsih, Stefanus M.M. Lumban Gaol 1)* \\ 1)Sekolah Tinggi Teologi Tawangmangu \\ *) Penulis korespondensi: Dwiatyuli123@gmail.com
}

Received: 03 June 2019 / Revised: 17 June 2019 / Accepted: 17 June 2019

\begin{abstract}
Abstrak
Salah satu tantangan dalam proses belajar mengajar di kelas adalah murid tidak antusias. Setiap guru mengharapkan selama mengajar di kelas semua murid antusias dan penuh minat. Kenyataannya tidak seperti itu, karena tidak semua guru memiliki kemampuan untuk mengatasi masalah murid yang kurang antusias. Oleh karena itu kajian tentang keterampilan guru dalam meningkatkan minat murid untuk belajar sangat diperlukan. Tujuan dari kajian ini untuk mendorong guru menambah keterampilan dalam melaksanakan tugasnya sehingga murid belajar dengan penuh perhatian. Penulis menggunakan metode deskriptif kualitatif yaitu menjelaskan istilah-istilah yang digunakan pada judul tulisan berdasarkan sumber yang berkaitan, dihubungkan dengan pengalaman penulis secara subyektif selama mengajar di kelas. Poin penting hasil kajian ini ialah guru harus memiliki ketrampilan untuk mengelola kelas dengan baik. Guru harus menguasai keterampilan untuk mulai pembukaan sampai pada penutupan kelas. Guru harus menguasai keterampilan dalam bertanya, menjelaskan, memberi penguatan, dan juga dalam membuat variasi. Keterampilan dalam pengelolaan kelas ini berpengaruh besar terhadap perhatian murid untuk belajar.
\end{abstract}

Kata kunci: Keterampilan, guru, minat, belajar, murid 


\section{Abstract}

One of the challenges in teaching and learning in the classroom is that students are not enthusiastic. Each teacher expects that while teaching in the class all students are enthusiastic and full of interest. The reality is not like that, because not all teachers have the ability to overcome the problem of students who are less enthusiastic. Therefore a study of teacher skills in increasing student interest in learning is very necessary. The purpose of this study is to encourage teachers to add skills in carrying out their duties so that students learn attentively. The author uses descriptive qualitative method that is to explain the terms used in the title of the writing based on related sources, associated with the author's experience subjectively during teaching in the classroom. The important point of the results of this study is that teachers must have the skills to manage the class well. The teacher must master the skills to begin opening until the closing of the class. The teacher must master the skills in asking, explain, give reinforcement, and also in making variations. Skills in managing this class have a big influence on students' attention to learning.

Key words: Skills, teachers, interests, learning, students

\section{Pendahuluan}

Proses belajar mengajar yang berlangsung di kelas akan berjalan dengan baik apabila terjadi interaksi yang optimal antara murid dan guru dalam rangka mencapai suatu tujuan. Salah satu tujuan pembelajaran yang ingin dicapai ialah murid dapat memperoleh prestasi belajar yang optimal. Seorang guru bukan hanya sekedar memberikan ilmu pengetahuan begitu saja tetapi memiliki peran yang sangat strategis bagaimana caranya membuat suasana belajar yang menarik dan menyenangkan sehingga murid dengan antusias mengikuti pelajaran dan dengan mudah memahami materi pelajaran yang diterimanya. Muara akhirnya tentu akan berpengaruh pada prestasi belajar murid.

Berdasarkan kenyataannya, guru tidak selalu mampu mewujudkan tercapainya tujuan mulia tersebut karena rendahnya gairah siswa untuk belajar. Dampaknya tentu kurang baik, di antaranya murid tidak dapat menguasai kompetensi atau tujuan pelajaran. Pembelajaran di kelas tidak jarang masih diselimuti oleh suasana belajar yang monoton, sehingga 
murid tidak bisa mengembangkan kreativitasnya, dan murid tidak tampak antusias dan penuh semangat dalam mengikuti pelajaran di kelas.

Pada proses pembelajaran masa kini kita tidak bisa menghindar dari apa yang sudah dilakukan secara konvensional dimana guru memberikan ceramah secara teoritis, memberikan tugas kemudian memberikan tes akhir dimana hal ini akan terulang secara terus menerus karena bagaimanapun hal ini akan tetap menjadi bagian secara integral dalam proses belajar mengajar di kelas termasuk pada mata pelajaran Pendidikan Agama Kristen (PAK). Cara pembelajaran seperti ini memang memiliki kecenderungan yang besar bagi murid untuk menjadi bosan dan akhirnya tujuan pembelajaran bisa tidak tercapai.

Oleh karena itu tugas guru sangat besar yaitu untuk membalikkan keadaan yang membosankan itu menjadi suasana yang menyenangkan sehingga murid memiliki minat belajar yang tinggi. Guru dituntut bukan hanya sekedar transfer ilmu kepada murid tetapi juga menciptakan suasana kelas yang menyenangkan. Untuk itu guru harus memiliki ketrampilanketrampilan yang diperlukan untuk memastikan proses belajar di kelas bukan saja berjalan lancar tetapi juga menyenangkan. Apalagi guru Pendidikan Agama Kristen (PAK) tentu mempunyai keunikan dibandingkan dengan guru-guru umum lainnya. Perbedaannya terletak pada karakter hidup seorang guru Kristen, karena seorang yang lahir dan hidup di dalam kekristenan pasti sudah mengetahui dan mengenal sosok pribadi yang penuh kasih, dan berkarakter sempurna yaitu Yesus Kristus. Sehingga seorang guru Kristen dituntut untuk hidup sesuai dengan karakter Kristus, demikian juga dalam cara mengajarnya tentu akan mengacu pada bagaimana Tuhan Yesus mengajar karena Dialah Sang Guru Agung itu.

\section{Metode Penelitian}

Metode penelitian yang digunakan dalam jurnal ini adalah metode diskriptif kualitatif artinya penulis akan menjelaskan dan memaparkan hakekat dasar dari istilah-istilah sesuai dengan judul tulisan ini yaitu Ketrampilan Guru Pendidikan Agama Kristen (PAK) Untuk Meningkatkan Minat Belajar Murid Dalam Proses Pembelajaran Di Kelas. Penjelasan didasarkan atas kajian dari sumber teks dan juga dari hasil pengamatan serta pengalaman penulis selama menjadi seorang guru. Konsep tentang ketrampilan guru akan didiskripsikan berdasarkan teks/sumber-sember 
tentang ilmu keguruan secara umum, pokok tentang Pendidikan Agama Kristen (PAK) digambarkan berdasarkan literatur Kristen dan Alkitab, dan pokok tentang minat murid akan dijelaskan berdasarkan sumber-sumber khususnya psikologis. Karena minat murid tidak dapat diukur secara nominal, maka akan diindikatorkan secara kualitatif dan bersifat subyektif. Tahap akhirnya adalah mengambil kesimpulan dari paparan di atas dengan mengacu pada gaya mengajar Tuhan sebagai Guru Agung seperti yang tertulis pada keempat kitab Injil.

\section{Pembahasan}

\section{Hakekat Ketrampilan Guru PAK (Pendidikan Agama Kristen)}

Menurut Kamus Besar Bahasa Indonesia (KBBI) keterampilan adalah kecakapan untuk menyelesaikan tugas. Dalam tulisan ini arti keterampilan yaitu kemampuan untuk menggunakan akal, fikiran, ide dan kreatifitas dalam mengerjakan, mengubah ataupun membuat sesuatu menjadi lebih bermakna sehingga menghasilkan sebuah nilai dari hasil pekerjaan tersebut ${ }^{1}$.

Menurut Undang-Undang no 14 tahun 2005 guru adalah pendidik profesional dengan tugas utama mendidik, mengajar, membimbing, mengarahkan, melatih, menilai, dan mengevaluasi peserta didik pada pendidikan anak usia dini jalur pendidikan formal, pendidikan dasar, dan pendidikan menengah ${ }^{2}$. Menurut Uzer Usman ${ }^{3}$ guru merupakan jabatan atau profesi yang memerlukan keahlian khusus, apalagi sebagai guru yang profesioanal yaitu orang yang memiliki kemampuan dan keahlian khusus dalam bidang keguruan sehingga ia mampu melakukan tugas dan fungsinya sebagai guru dengan kemampuan khusus.

Bahkan mengenai jabatan guru sebagai tenaga profesional ditegaskan pula dalam Undang-undang RI No. 20 tahun 2003 pasal 39 ayat 2 tentang Sistem Pendidikan Nasional yang menyatakan bahwa pendidik merupakan tenaga profesional yang bertugas merencanakan dan melaksanakan proses pembelajaran, menilai hasil pembelajaran, melakukan

\footnotetext{
${ }^{1}$ Kamus Besar Bahasa Indonesia (Jakarta: Balai Pustaka, 2001), 1088

${ }^{2}$ Undang Undang Republik Indonesia No 14 Tahun 20005 Tentang Guru dan Dosen (Jakarta: Depdiknas, 2005), 2

${ }^{3}$ Uzer Usman, Menjadi Guru Profesional (Jakarta: Remaja Rosdakarya, 2006), 5
} 
pembimbingan dan pelatihan, serta melakukan penelitian dan pengabdian kepada masyarakat terutama bagi pendidik pada perguruan tinggi. ${ }^{4}$

Dari pengertian di atas dapat dikatakan bahwa guru adalah seorang yang memiliki keahlian dan kemampuan khusus dalam bidangnya. Dengan demikian dapat dikatakan bahwa hakikat keterampilan guru adalah kecakapan dari seorang tenaga profesional yang tugas utamanya ialah mendidik, mengajar, membimbing, mengarahkan, melatih, menilai, dan mengevaluasi dalam mengubah atau membuat sesuatu yang dikerjakan lebih bermakna.

\section{Pengertian PAK (Pendidikan Agama Kristen) Pendidikan}

Pendididkan adalah salah satu aspek yang sangat penting dan strategis dalam kehidupan manusia. Sebagai sesuatu yang khas dan spesifik bagi manusia, pendidikan berperan amat signifikan dalam membekali manusia untuk menyongsong masa depan yang akan dijalani murid yang diwarnai dengan berbagai tantangan dan perubahan.

Menurut Undang-Undang Republik Indonesia Nomor 20 Tahun 2003 tentang Sistem Pendidikan Nasional atau yang lebih dikenal dengan sebutan Undang-Undang Sistem Pendidikan Nasional (UUSPN) Bab I pasal 1 dinyatakan bahwa pendidikan adalah usaha sadar dan terencana untuk mewujudkan suasana belajar dan proses pembelajaran agar peserta didik secara aktif mengembangkan potensi dirinya untuk memiliki kekuatan spiritual keagamaan, pengendalian diri, kepribadian, kecerdasan, akhlak mulia, serta keterampilan yang diperlukan dirinya, masyarakat, bangsa, dan negara. Secara etimologis pendidikan berasal dari kata latin 'educates' dengan istilah educare atau educere yang berarti merawat dan melengkapi dan juga membimbing keluar.

Berdasarkan pengertian ini dapat dikatakan bahwa pendidikan adalah sebagai upaya sadar dan sengaja untuk memperlengkapi seseorang atau kelompok orang untuk membimbingnya keluar dari suatu tahapan (keadaan) hidup ke suatu tahapan hidup lainnya yang lebih baik. ${ }^{5}$

\footnotetext{
${ }^{4}$ Undang-Undang Republik Indonesia No 20 Tahun 2003 Tentag Sistem Pendidikan Nasional ( Jakarta: Pustaka Pelajar, 2003), 24

${ }^{5}$ Samuel Sijabat, Strategi Pendidikan Kristen ( Yogjakarta:19994), 15
} 


\section{Agama Kristen}

Menurut Kamus Besar Bahasa Indonsia, agama adalah sistem yang mengatur tata keimanan (kepercayaan) dan peribadatan kepada Tuhan Yang Maha Kuasa serta tata kaidah yang berhubungan pergaulan manusia dengan sesama dan lingkungannya. Agama Kristen adalah suatu sistem kepercayaan atau ajaran yang yang bersumber dan bermuara kepada Allah didalam Yesus Kristus. Sistem kepercayaan atau ajaran yang meyakini bahwa tindakan Allah yang dalam kasihNya mencari dan menyelamatkan manusia ( $R m$ 5:8, Yoh 3: Efe 2:8-9).

Tuhan Allah tahu bahwa manusia tidak akan mampu mendekati dan menjangkau Allah, yang tidak terbatas tak mungkin didekati oleh yang terbatas oleh karena itu Allah mendekati manusia, Ia menyatakan diriNya kepada manusia, agar manusia mengenalNya, menurut Alkitab, kalaupun manusia mengasihi dan beriman kepada Tuhan, hal itu terjadi karena Allah telah terlebih dahulu mencari, mengasihi dan menyelamatkan manusia (Amos 5:4-5 dan Yoh 4:21-26).

Inisiatif untuk memulihkan hubungan ini ada pada Allah sendiri, tindakan manusia seperti iman, ketaatan, perhatian pada titah Allah dan sebagainya adalah tanggapan manusia terhadap inisiatif Allah (Mzr 103:1-4, Rm 7:25, Yoh 14:26). Dengan demikian agama Kristen adalah agama yang muncul sebagai perwujudan tanggapan manusia atas inisiatif Allah, bukan sebagai manusia yang mencari Allah.

Dengan demikian dapat dikatakan Pendidikan Agama Kristen (PAK) adalah proses pengajaran dan pembelajaran yang berdasarkan Alkitab, berpusat pada Kristus dan bergantung kepada Roh Kudus yang membimbing setiap pribadi pada semua tingkat pertumbuhan melalui pengajaran masa kini ke arah pengenalan dan pengalaman rencana dan kehendak Allah melalui Kristus dalam setiap aspek kehidupan, dan melengkapi bagi pelayanan yang efektif, yang berpusat pada Kristus sang Guru Agung.

Oleh karena itu tujuan utama Pendidikan Agama Kristen (PAK) Menurut John M. Nainggolan ${ }^{6}$ adalah mengajarkan Firman Tuhan,

\footnotetext{
${ }^{6}$ Johan M. Nainggolan, Menjadi Guru Agama Kristen (Jakarta: Generasi Info Media, 2007), 12
} 
membawa perjumpamaan dengan Kristus, mengajarkan hidup bersama, dan membawa murid untuk memiliki spiritualitas seperti Kristus.

Sedangkan materi utama dalam PAK (Pendidikan Agama Kristen) adalah Alkitab karena Alkitab adalah Firman Allah yang tertulis. Pembelajaran terhadap Alkitab sebagai Firman yang tertulis membawa secara pasti perjumpamaan dengan Yesus Kristus sebagai penjelmaan dari Firman Allah. Dan perjumpamaan dengan Yesus Kristus Yesus secara pribadi menjanjikan adanya perubahan-perubahan mendasar dalam karakter seseorang, dengan karakter yang diperbaharui ini akan berpengaruh dalam berhubungan dengan sesamanya. Jadi muara akhir dari belajar Pendidikan Agama Kristen (PAK) adalah memiliki karakter seperti karakter Tuhan Yesus Kristus bukan karakter pemalas atau kurang antusias.

\section{Pengertian Minat Belajar Murid Dalam Proses Pembelajaran di Kelas}

Arti minat menurut Kamus Besar Bahasa Indonesia adalah sebagai perhatian, kecenderungan hati terhadap sesuatu, gairah, atau keinginan. Menurut Lusi Nurhayati ${ }^{7}$ minat adalah kecenderugan terhadap sesuatu, atau bisa dikatakan apa yang disukai seseorang terhadap sesuatu atau apa yang disukai seseorang untuk dilakukan. Sedangkan menurut Alisuf Sabri ${ }^{8}$ minat adalah kecenderungan untuk selalu memperhatikan dan mengingat sesuatu secara terus menerus. Dan minat ini dikaitkan dengan rasa senang seorang, karema minat itu terjadi karena sikap senang terhadap sesuatu.

Dengan demikian dapat dikatakan bahwa minat adalah kecenderungan yang dibarengi dengan perasaan senang terhadap sesuatu baik berupa benda maupun kegiatan begitu pula dengan kegiatan belajar. Dengan adanya minat dalam diri seseorang maka kegiatan seberat apapun akan terasa ringan dan menyenangkan manakala melakukannya, dengan melakukan kegiatan yang penuh semangat akan menghasilkan kerja yang lebih baik.

\footnotetext{
${ }^{7}$ Lusi Nurhayati, Psikologi Anak (Jakarta PT Indeks, 2008), 59

${ }^{8}$ Alisuf Sabri, Psikologi Pendidikan (Jakarta:CV Pedoman Ilmu Jaya, 2007), 8
} 


\section{Macam-Macam Minat}

Menurut Ahmad Susanto ${ }^{9}$ timbulnya minat pada seseorang dapat digolongkan menjadi dua jenis yaitu minat murid yang berasal dari bawaan dan minat murid yang timbul karena pengaruh dari luar dirinya. Minat bawaan timbul dengan sendirinya dari setiap individu. Sedangkan minat yang timbul karena adanya pengaruh dari luar dirinya timbul seiring dengan perkembangan individu yang bersangkutan. Dan minat ini sangat dipengaruhi oleh lingkungannya, adat atau kebiasaan, orang tua, guru, dan juga teman-temannya.

\section{Indikator minat}

Minat merupakan kekuatan motivasi yang menyebabkan seseorang memusatkan perhatian terhadap seseorang, suatu benda, atau kegiatan tertentu. Oleh karena itu ada indikator yang dapat disimak yang mencerminkan ada tidaknya minat dalam diri murid.

Pertama, perasaan senang, jika seorang murid memiliki perasaan senang terhadap mata pelajaran Pendidikan Agama Krsten (PAK) misalya, maka murid tersebut dapat dikatakan memiliki minat terhadap mata pelajaran Pendidikan Agama Kristen (PAK) tersebut. Perasaan senang ini akan mengusir rasa bosan yang menghinggapi murid dan dengan antusias murid akan mengikuti pelajaran dengan rajin hadir dan murid akan melakukan setiap tugas yang diberikan pada mata pelajaran Pendidika Agama Kristen (PAK) ini.

Kedua, perhatian, indikator berikutnya adalah perhatian yang merupakan konsentrasi atau aktivitas jiwa seorang murid terhadap apa yang sedang dijalani dengan mengesampingkan hal lainnya. Seorang murid yang memiliki minat terhadap mata pelajaran tertentu akan memiliki kecenderungan yang kuat untuk memberikan perhatian yang lebih terhadap obyek yang diminatinya.

Ketiga, memiliki pengetahuan dan rasa ingin tahu lebih. Seorang murid yang telah memiliki pengetahuan tertentu maka pengetahuan itu akan menyebabkan dia menjadi murid yang lebih berminat. Sisi lain dapat juga dikatakan karena rasa ingin tahu lebih terhadap apa yang sudah diketahuinya

\footnotetext{
${ }^{9}$ Ahmad Susanto, Teori Belajar Dan Pembelajaran (Jakarta: Kencana Prenada Media Grup, 2013), 60
} 
itu mencerminkan tingkat minat dari seorang murid dan sekaligus menjadi dorongan untuk mengembangkan rasa tahu itu menjadi lebih besar lagi.

Keempat, rasa tertarik, seorang murid yang berminat terhadap sesuatu pelajaran maka murid tersebut akan tertarik dengan hal yang berkaitan dengan itu seperti guru, mata pelajaran, dan juga murid yang lainnya.

Dari ke-empat indikator minat di atas yaitu rasa senang, perhatian, rasa ingin tahu dan juga rasa tertarik ini semua bersifat kualitatif. Kualifikasi seorang murid yang dikatakan berminat dalam belajar tentu tidak bisa dipisahkan dari ke empat indikator tersebut.

Dengan demikian dapat dikatakan bahwa minat belajar murid di kelas adalah tingkat kecenderungan yang kuat dari seorang murid yang ditandai dengan rasa senang, tertarik, perhatian, dan rasa ingin tahu dalam berinteraksi dengan guru dan murid yang lain selama mengikuti proses belajar di kelas mulai awal pelajaran sampai akhir.

\section{Hakikat Belajar}

Belajar adalah suatu proses yang kompleks yang terjadi pada diri setiap orang sepanjang hidupnya. Menurut Slameto ${ }^{10}$ belajar ialah suatu proses usaha yang dilakukan seseorang untuk memperoleh suatu perubahan tingkah laku yang baru secara keseluruhan, sebagai hasil pengalamannya sendiri dalam interaksi dengan lingkungannya. Sedangkan Sardiman ${ }^{11}$ menyatakan belajar merupakan perubahan tingkah laku atau penampilan, dengan serangkaian kegiatan misalnya dengan membaca, mengamati, mendengarkan, meniru dan lain sebagainya.

Dari pendapat para ahli dapat diambil kesimpulan bahwa belajar proses perubahan tingkah laku seseorang atau individu sebagai akibat interaksi dengan lingkungannya yang berlangsung sepanjang hidupnya dengan serangkaian kegiatan membaca, mengamati, mendengarkan, meniru, dan yang lainnya yang bertujuan untuk mendapatkan pengetahuan, penanaman konsep dan keterampilan, dan pembentukan sikap.

${ }^{10}$ Slameto, Belajar dan Faktor-Faktor Yang Mempengaruhinya (Jakarta: Remeka Cipta, 2010), 15

${ }^{11}$ Sardiman, Interaksi Dan Motivasi Belajar dan Mengajar (Jakarta: Rajawali Pers, 2011), 20 


\section{Pengertian Pembelajaran}

Pembelajaran menurut beberapa para ahli, sebagai berikut, menurut Hamdani 12 pada hakikatnya, pembelajaran (belajar dan mengajar) merupakan proses komunikasi antara guru dan siswa. Menurut Suprijono ${ }^{13}$ pembelajaran berpusat pada peserta didik, merupakan dialog interaktif, proses organik dan konstruktif, bukan mekanis seperti halnya pengajaran. Sedangkan menurut Yamin ${ }^{14}$ pembelajaran adalah suatu usaha yang disengaja, bertujuan dan terkendali agar orang lain belajar atau terjadi perubahan yang relatif menetap pada diri orang lain.

Dengan demikian dapat dikatakan bahwa pembelajaran adalah membelajarkan murid, artinya sebuah upaya yang dilakukan guru sehingga tingkah laku siswa berubah ke arah yang lebih baik dan sebuah usaha guru dalam menciptakan iklim dan pelayanan terhadap kemampuan, potensi, minat, bakat dan kebutuhan murid yang amat beragam agar terjadi interaksi optimal, antara guru dan murid serta antarmurid.

Dengan kata lain pembelajaran merupakan suatu proses atau upaya menciptakan kondisi belajar dalam mengembangkan kemampuan minat dan bakat siswa secara optimal, sehingga kompetensi dan tujuan pembelajaran dapat tercapai. Hal tersebut juga sejalan dengan Undang-Undang Nomor 20 Tahun 2003 tentang Sistem Pendidikan Nasional yang menjelaskan bahwa pembelajaran adalah proses interaksi antara siswa, guru dan sumber belajar pada satu lingkungan belajar.

Dengan demikian lima unsur penting dalam sebuah proses pembelajaran adalah sebagai berikut, pertama, pembelajaran bertujuan memberikan bantuan agar belajar murid menjadi efektif dan efisien. Jadi guru hanyalah pemberi bantuan dan bukan penentu keberhasilan atau kegagalan belajar siswa. Kedua, pembelajaran bersifat terprogram. Pembelajaran dirancang untuk tujuan jangka pendek, menengah ataupun jangka panjang. Ketiga, pembelajaran dirancang melalui pendekatan sistem. Karena bila dirancang secara sistematis dipercaya akan mempengaruhi perkembangan murid secara individual. Keempat, pembelajaran yang

\footnotetext{
${ }^{12}$ Hamdani, Strategi Belajar Mengajar (Bandung: Pustaka Setia, 2011), 72

${ }^{13}$ Suprijono, Cooperative Learning (Yogjakarta: Pustaka Pelajar, 2013), 13

${ }^{14}$ Yamin, Strategi Dan Metode Dalam Model Pembelajaran (Jakarta: Referensi (GP Press Group,2013), 15
} 
Keterampilan Guru PAK...(Dwiati Yulianingsih, Stefanus)

dirancang harus sesuai berdasarkan pendekatan sistem. Kelima, pembelajaran dirancang berdasarkan pengetahuan tentang teori belajar.

\section{Komponen dan Sifat Pembelajaran}

Komponen Pembelajaran

Menurut Hamdani ${ }^{15}$ dalam pembelajaran melibatkan enam komponen, sebagai berikut: pertama adalah tujuan, yang secara eksplisit diupayakan melalui kegiatan pembelajaran instructional effect, biasanya berupa pengetahuan dan keterampilan atau sikap yang dirumuskan secara eksplisit dalam tujuan pembelajaran. Kedua, komponen subjek belajar, dimana sistem pembelajaran merupakan komponen utama karena berperan sebagai subjek sekaligus objek. Ketiga, komponen materi pelajaran yang merupakan komponen utama dalam proses pembelajaran karena materi pelajaran akan memberi warna dan bentuk kegiatan pembelajaran. Keempat, komponen strategi pembelajaran yang merupakan pola umum mewujudkan proses pembelajaran yang diyakini efektivitasnya untuk mencapai tujuan pembelajaran. Kelima, komponen media pembelajaran adalah alat atau wahana untuk digunakan guru dalam proses pembelajaran untuk membantu penyampaian pesan pembelajaran. Media pembelajaran berfungsi meningkatkan peranan strategi pembelajaran. Dan yang keenam, komponen penunjang yang dalam sistem pembelajaran adalah fasilitas belajar, sumber belajar, alat pengajaran, bahan pelajaran dan semacamnya. Penunjang berfungsi memperlancar dan mempermudah terjadinya proses pembelajaran.

\section{Sifat Pembelajaran}

Lima sifat pembelajaran aktif, inovatif, kreatif, efektif dan menyenangkan. Aktif dimaksudkan bahwa dalam proses pembelajaran guru harus menciptakan suasana sedemikian rupa sehingga siswa aktif bertanya, mempertanyakan, dan mengemukakan gagasan. Pembelajaran inovatif bisa mengadaptasi dari model pembelajaran yang menyenangkan. Learning is fun merupakan kunci yang diterapkan dalam pembelajaran inovatif. Jika murid sudah menanamkan hal ini di pikirannya tidak akan ada lagi murid yang pasif di kelas, perasaan tertekan dengan tenggat waktu tugas, kemungkinan kegagalan, keterbatasan pilihan, dan tentu saja rasa bosan.

${ }^{15}$ Hamdani, Strategi Belajar Mengajar (Bandung: Pustaka Setia, 2011), 48 
Kreatif dimaksudkan agar guru menciptakan kegiatan belajar yang beragam sehingga memenuhi berbagai tingkat kemampuan siswa. Menyenangkan adalah suasana belajar-mengajar yang menyenangkan sehingga siswa memusatkan perhatiannya secara penuh pada belajar sehingga waktu curah perhatiannya ("time on task") tinggi. Tingginya waktu curah perhatian terbukti meningkatkan hasil belajar.

Keadaan aktif dan menyenangkan tidaklah cukup jika proses pembelajaran tidak efektif, yaitu tidak menghasilkan apa yang harus dikuasai murid setelah prosespembelajaran berlangsung, sebab pembelajaran memiliki sejumlah tujuan pembelajaran yang harus dicapai. Jika pembelajaran hanya aktif dan menyenangkan tetapi tidak efektif, maka pembelajaran tersebut tak ubahnya seperti bermain biasa saja.

Keterampilan Guru Pendidikan Agama Kristen (PAK) dalam Meningkatkan Minat Belajar murid Di Kelas

Menurut Rusman ${ }^{16}$ ada delapan ketrampilan dasar dari seorang guru profesional yaitu bertanya, memberi penguatan, mengadakan variasi, menjelaskan, membuka dan menutup pelajaran, membimbing diskusi kelompok kecil, mengelola kelas, dan mengajar kelompok kecil atau perorangan. Dari delapan ketrampilan guru di atas , lima ketrampilan guru yang pertama bertalian secara langsung dengan proses belajar di kelas dan secara sporadis dijadikan kisi-kisi dalam pembahasan ini.

Keterampilan Guru Pendidikan Agama Kristen (PAK) dalam meningkatkan minat belajar murid di kelas akan dibahas dalam tiga tahapan yaitu pertama membuat pembukaan pelajaran yang menarik, kedua memastikan proses belajar -mengajar di kelas berjalan dengan baik, dan yang ketiga membuat penutupan yang mengesankan.

Membuka Pelajaran di Kelas Yang menarik (set induction skills).

Keterampilan membuka pelajaran adalah kegiatan yang dilakukan oleh guru guna menciptakan situasi agar murid siap mental untuk menaruh perhatian yang terpusat pada apa yang akan dipelajari. Disamping itu, murid

16 Rusman, Model-Model Pembelajaran:Mengembangkan Profesionalisme Guru (Jakarta: Raja Grafindo Persada, 2014), 70 
memerlukan motivasi yang tinggi supaya mengikuti pembelajaran sampai selesai dengan semangat dan penuh konsentrasi.

\section{Prinsip Dalam Membuka Pelajaran}

Ada dua prinsip dalam membuka pelajaran yaitu prinsip keberrmaknaan dan prinsip berkesinambungan. Prinsip kebermaknaan guru menarik perhatian murid dengan menggunaan cara-cara yang bermanfaat dan memiliki relevansi dengan materi pelajaran. Sedangkan prinsip berurutan dan berkesimabungan yaitu kegiatan yang sistematis dan berkaitan antara satu bagian dengan bagian lainnya atau berkaitan dengan pengetahuan awal para murid. Oleh karena itu dalam bagian ini guru penting untuk mengingatkan murid tentang materi yang sudah dipelajari pada pertemuan sebelumnya.

Seperti yang dikisahkan dalam Matius 16:5-10, setelah Tuhan Yesus mengadakan mujizat memberi makan lima ribu orang yang kemudian dilanjutkan dengan mujizat memberi makan empat ribu orang, Tuhan Yesus bersama muridNya menyeberangi danau. Pada waktu menyeberang danau Tuhan Yesus berpesan kepada murid-muridNya untuk berjaga-jaga dan berwaspada terhadap ragi orang Farisi dan Saduki. Murid-murid berpikir bahwa Tuhan Yesus berkata seperti itu karena mereka lupa membawa roti. Murid-murid ditegur Tuhan Yesus seperti orang yang tidak percaya. Dan kemudian murid-murid diingatkan akan mujizat tentang lima roti untuk lima ribu orang itu dengan sisanya 12 bakul. Demikian juga tentang tujuh roti untuk empat ribu orang itu.

Langkah Tuhan Yesus untuk mengingatkan kepada para murid atas apa yang telah terjadi ini merupakan pelajaran penting bagi para murid untuk selalu mengingatnya. Materi pelajaran hari ini adalah kelanjutan dari materi dari pertemuan sebelumnya. Demkian juga materi hari ini akan dilanjutkan pada pertemuan yang akan datang. Guru memegang prinsip berkesinambungan ini supaya murid pada akhirnya akan menerima komprehensivitas materi pelajaran yang bertalian dari awal pertemuan sampai pada akhirnya.

\section{Memastikan Proses Belajar Berlangsung dengan Baik}

Dalam memastikan proses belajar-mengajar di kelas berjalan baik, ada empat ketrampilan penting yang perlu diperhatikan oleh guru yaitu 
ketrampilan bertanya, penguatan, mengadakan variasi, dan ketrampilan dalam menjelaskan.

\section{Ketrampilan Bertanya (questioning skills)}

Bertanya adalah salah satu cara yang dapat dipakai oleh guru untuk membantu murid menerima informasi atau untuk mengembangkan ketrampilan kognitif yang lebih tinggi. Pokok penting yang selalu diingat berkaitan dengan ketrampilan bertanya ini antara lain tujuan pertanyaan, susunan kata-kata dalam mengajukan pertanyaan, struktur pertanyaan, ruang lingkup pertanyaan, pindah gilir yaitu pemberian pertanyaan kepada beberapa murid secara berurutan, pendisitribusian pertanyaan secara acak, pemberian kesempatan kepada murid untuk memikirkan jawaban, dan penuntunan kepada murid untuk bisa menjawab pertanyaan dengan baik dan benar, serta pengubahan pertanyaan berdasarkan tingkat kognitif.

Dalam benak guru ada terkandung maksud dari setiap pertanyaan yang diberikan kepada murid kecuali pertanyaannya akan menjadi sia-sia dan kontraproduktif. Susunan kata-kata dalam pertanyaan disesuaikan dengan tingkat pemahaman murid supaya mudah untuk dimengerti. Isi pertanyaan tidak keluar dari ruang lingkup materi yang sedang dipelajari. Demikian juga kepada siapa pertanyaan itu ditujukan, guru memiliki alasan mendasar supaya proses belajar-mengajar di kelas berjalan baik.

Sedangkan hal yang harus dihindari seorang guru dalam kaitannya dengan bertanya ini adalah mengulangi pertanyaan sendiri, mengulangi jawaban murid, menjawab pertanyaan sendiri, dan meminta jawaban secara serentak.

Dalam kitab Injil mencatat bahwa Tuhan Yesus dalam mengajar sering mengajukan pertanyaan kepada murid-muridNya. Empat diantaranya adalah sebagai berikut: Pertama, dalam Injil Matius 26:8 Tuhan Yesus mengajukan pertanyaan "Mengapa kamu takut, kamu yang kurang percaya". Pertanyaan ini disampaikan untuk mengukur kadar iman para murid dan sekaligus bertujuan untuk membawa kembali tingkat kepercayaan yang lebih tinggi dari para murid kepada Nya.

Pertanyaan kedua tercatat dalam Injil Matius 16:15, 'Tetapi apa katamu, siapakah Aku ini?" Pertanyaan yang diajukan Tuhan Yesus ini memancing para murid untuk berani menyampaikan pendapat, persepsi, dan gambaran para murid tentang siapa Tuhan Yesus itu. Murid membutuhkan 
perasaan nyaman untuk bisa menyampaikan apa yang dipikirkan dan dirasakannya.

Pertanyaan ketiga Tuhan Yesus kepada murid-muridNya tercatat di Mat 26:40b Dan Ia berkata kepada Petrus: "Tidakkah kamu sanggup berjaga-jaga satu jam dengan Aku? Dengan pertanyaan ini Tuhan Yesus membangkitan rasa tertantang dari murid. Sejatinya murid sanggup untuk berjagajaga satu jam bersama-sama dengan-NYa jika mereka memiliki kemauan dan tekat yang kuat. Guru kreatif memilih kata-kata dalam pertanyaan untuk memancing mengeluarkan potensi murid melalui pertanyaan ini.

Pertanyaan keempat tertulis dalam Mat 15:34. Kata Yesus kepada mereka: "Berapa roti ada padamu?" Kontkesnya adalah semua orang yang mengikuti Tuhan Yesus harus makan karena kelelahan dan waktu sudah larut, sedangkan mereka berada jauh dari perkampungan. Dalam situasi seperti inilah muncul pertanyaan Tuhan Yesus 'Berapa roti ada padamu?' Dengan pertanyaan ini, Tuhan Yesus sedang hendak melibatkan para murid untuk memecahkan suatu persoalan yang sedang dihadapi bersama. Karena materi ajarnya adalah tentang iman, oleh karena itu Tuhan Yesus menanyakan apa yang ada pada murid bukan apa yang tidak ada.

Guru Pendidikan Agama Kristen (PAK) harus memiliki kepekaan tingkat tinggi dalam melihat adanya kebutuhan apa yang sedang dihadapi para murid di kelas. Dengan tanggap dan cepat guru bertindak untuk memenuhi kebutuhan tersebut dengan cara melibatkan para murid dan salah satunya caranya ialah dengan mengajukan pertanyaan yang tepat.

\section{Ketrampilan Dalam Memberi Penguatan (Reinforcement Skills)}

Menurut Winataputra ${ }^{17}$ penguatan adalah respon yang diberikan terhadap perilaku atau perbuatan yang dianggap baik, yang dapat membuat terulangnya atau meningkatnya perilaku atau perbuatan yang dianggap baik tersebut. Penguatan dapat diberikan dalam dua bentuk yaitu verbal dan non verbal. Bentuk-bentuk penguatan yang lebih detail yaitu penguatan verbal, penguatan gestural, penguatan kegiatan, penguatan mendekati, penguatan sentuhan, dan penguatan tanda.

Empat prinsip dalam memberikan penguatan antara lain guru dalam memberikan penguatan bersikap hangat dan antusias, mengindari pemberian

\footnotetext{
${ }^{17}$ Winataputra, Strategi Belajar Mengajar (Jakarta: Universitas Terbuka Departemen Penddikan Nasional, 2007), 7-8
} 
penguatan yang bersifat negatif, memberikan penguatan dengan cara yang bervariasi, dan memperhatikan kebermaknaan dalam memberikan penguatan.

Ketika Tuhan Yesus mengajar dengan perumpamaan tentang talenta (Matius 35:14-30), kepada hamba yang memiliki dua dan lima talenta yang telah mengembangkan talenta menjadi dua kali llipat itu dipuji dengan menyatakan bahwa perbuatannya itu baik sekali. Karena telah setia dalam perkara kecil maka tuannya akan menyiapkan tanggungjawab yang lebih besar.

Ketika seorang murid mendengar pujian/penguatan, murid akan merasa besar hati dan bersukacita. Perasaan bangga dan sukacita ini mendorongnya untuk mengulangi melakukannya kembali di kemudian hari dengan ukuran yang lebih besar lagi. Guru harus secara kretaif perlu mengembangkan ketrampilan penguatan ini terhadap murid supaya ketika murid mendengar penguatan ini merasa dihargai dan minat belajarnya pasti tergugah.

\section{Ketrampilan Mengadakan Variasi (Variation Skills)}

Tujuan penggunaan variasi adalah untuk mengatasi kejenuhan dan kebosanan sehingga suasana yang monoton dapat dihindari karena murid dengan antuisias dan penuh minat dalam mengikuti proses pembelajaran di kelas. Guru dapat bervariasi dalam penggunaan gaya mengajar, penggunaan media dan bahan ajar, serta dalam berinteraksi dengan murid apabila terlihat perhatian dan minat murid berkurang. Variasi gaya mengajar guru meliputi variasi suara, penekanan (focusing), kontak pandang, gerakan anggota badan (gesturing), dan pindah posisi.

Tujuan variasi media dan bahan ajar adalah untuk memenuhi kebutuhan murid yang memiliki tingkat kemampuan indra yang berbeda. Kreatitivas guru dalam penggunaan variasi media pandang, media dengar dan media taktik, serta dikaitkan dengan bahan ajar yang variatif akan menciptakan suasana belajar yang menyenangkan.

Jika melihat kreativitas Tuhan Yesus dalam mengajar akan didapati paling tidak dalam dua bentuk yaitu variasi lokasi dan variasi metode mengajar. Lokasi pengajaran Tuhan Yesus dapat berlangsung di bukit, pantai, dan di dalam ruang. Sedangkan metode mengajarNya disamping dengan mengajukan pertanyaan, Tuhan Yesus sering menggunakan 
perumpamaan. Dalam Markus 4:2 mencatat bahwa Tuhan Yesus mengajar dengan menggunakan banyak perumpamaan. Archibald Hunter mengklaim bahwa 35 persen dari ajaran Tuhan dalam ke empat kitab Injil berbentuk perumpamaan ${ }^{18}$.

Guru harus memiliki pemahaman yang benar tentang kebutuhan mendasar apa yang sedang dibutuhkan untuk memecahkan kebekuan suasana di kelas. Dengan tersedianya perbendaharaan variasi, guru terampil untuk menggunakannya sesuai dengan kebutuhan yang ada sehingga suasana yang membosankan dapat diganti dengan suasana yang menyenangkan dan menarik minat murid.

\section{Keterampilan Menjelaskan ( Explaining Skills)}

Keterampilan menjelaskan adalah penyajian informasi secara lisan yang terorganisir secara sistematis untuk menunjukkan adanya hubugan antara satu dengan lainnya, contohnya hubungan sebab akibat. Dengan kata lain menjelaskan itu berarti mengorganisasikan materi palajaran dalam tata urutan yang terencana secara sistematis, sehinggga dengan mudah murid dapat memahaminya.

Tujuan dari menjelaskan adalah untuk membimbing murid memahami materi secara obyektif, melibatkan murid untuk berfikir memecahkan masalah atau menjawab suatu pertanyaan, memperoleh umpan balik dari murid untuk mengetahui tingkat pemahaman murid, dan membimbing murid memperoleh pengetahuan yang lebih bermakna dari proses penyelesaian masalah.

Kotbah di bukit (Matius 5-7) adalah contoh bentuk ceramah pengajaran Tuhan Yesus yang berisi nilai-nilai moral dan spiritual. Materi kotbah di bukit secara jelas dapat dilihat tingkat keteraturannya dan sistematika isinya, sehingga dengan mudah para murid dapat menyimaknya. Respon yang diharap dari para murid adalah pengertian yang lebih mendalam dan perubahan tingkah laku.

Tantangan bagi seorang guru adalah bagaimana memiliki ketrampilan menjelaskan dengan cara yang menarik minat murid, karena pada bagian menjelaskan ini biasanya adalah bagian dimana murid sering mengalami kebosannan dan kemonotonan. Setelah mendengarkan 
pengajaran Tuhan Yesus di atas bukit, orang banyak merasa takjub karena Tuhan Yesus mengajar (menjelaskan) dengan penuh kuasa tidak seperti para pengajar pada waktu itu (Matius 7:28-29).

Tiga prinsip yang diambil adalah ketika guru menjelaskan harus dengan penuh keyakinan. Keyakinan didapat dari pengandalan seorang guru kepada kuasa Roh Kudus bahwa dengan penuh urapanNya guru dapat menjelaskan dengan penuh kepercayaan. Kedua, seorang guru menguasai materi pelajarannya dengan baik. Tingkat penguasaan materi oleh seorang guru berpengaruh terhadap kemantapan dan kelancaran dalam penyampaiannya. Dan yang ketiga, seorang guru dalam menjelaskan memperhatikan intonasi serta nada suara supaya dapat menjangkau semua pendengar secara jelas.

\section{Membuat Penutupan Belajar di Kelas yang Mengesankan}

Keterampilan menutup pelajaran adalah kegiatan yang dilakukan guru untuk memberikan gambaran menyeluruh tentang apa yang dipelajari murid yaitu mengetahui tingkat pencapaian murid. Komponen dalam menutup kelas, yaitu review dan evaluasi.

Review adalah mengulang kembali poin-poin penting dan kemudian meminta murid untuk mengungkapkannya kembali melalui pertanyaan atau membuat rangkuman dari materi yang telah dipelajari. Sedangkan evaluasi dapat dilakukan dengan cara meminta murid mendemontrasikan, mengaplikasikan konsep, curah pendapat, atau mengerjakan soal tertulis.

Pada tahap penutupan pelajaran ini guru memberikan dorongan secara psikologis dan rohani. Dorongan secara psikologis mencakup tiga aspek yaitu aspek kognitif, afektif, dan psikomotorik. Bentuk dorongan dari aspek kognitif, guru merangkum kembali poin-poin penting selama pembelajaran mulai dari awal sampai pada akhirnya. Dorongan dari aspek afektif berupa sentuhan pada penjiwaan murid sehingga murid menanam kesan yang dalam atas materi yang baru dipelajarinya. Dorongan dari aspek psikomotorik, guru berpusat pada aspek kehendaknya sehingga terjadi dorongan yang begitu kuat atas murid untuk menerapkan semua pengetahuan yang baru dipelajarinya dalam kehidupan sehari-hari.

Berkaitan dengan dorongan secara rohani, guru Pendidikan Agama Kristen (PAK) akan mengambil kesempatan pada bagian penutup ini untuk menegaskan dan menancapkan benih-benih Firman Tuhan sebagai materi 
ajar kepada para murid. Murid diyakinkan secara persuasif untuk menghayati kebenaran materi/Firman Tuhan yang baru dipelajari dalam kehidupannya, membangun hubungan secara pribadi dengan Tuhan Yesus secara lebih intens, dan berfokus pada pribadi Yesus Krsitus untuk dijadikan standar dalam semua aspek kehidupannya.

Dan akhirnya seorang guru memberikan petunjuk untuk topik berikutnya dalam pertemuan yang akan datang. Mental murid lebih disiapkan demikian juga dengan semua properti yang diperlukan supaya pertemuan berikutnya berjalan lebih baik lagi.

\section{Kesimpulan}

Dari paparan di atas dapat ditarik kesimpulan sebagai berikut: keterampilan guru Pendidikan Agama Kristen (PAK) dalam menciptakan suasana kelas yang kondusif sehingga proses belajar berjalan baik adalah sangat dibutuhkan. Guru Pendidikan Agama Kristen (PAK) bertanggung jawab bukan hanya menyampaikan materi ajar saja tetapi juga harus terampil untuk mengatasi segala hambatan belajar di kelas khususnya karena faktor murid yang tampak kurang antusias dan kurang berminat dalam mengikuti pelajaran di kelas.

Guru Pendidikan Agama Kristen (PAK) harus menguasai keterampilan dasar dalam menjalankan tugasnya. Penguasaaan keterampilan dasar mulai dari cara membuka kelas sampai penutupan mutlak dikuasai oleh guru supaya murid tetap berminat tinggi dan penuh antusias dalam belajar. Dan tidak kalah pentingnya karena guru Pendidikan Agama Kristen (PAK) adalah orang-orang yang sudah lahir baru dan percaya sepenuhnya kepada Tuhan Yesus, maka dalam menjalankan tugasnya itu selalu berpedoman kepada kiprah dan apa yang Tuhan Yesus telah lakukan setiap kali mengajar para muridNya supaya murid pada akhirnya memiliki kesan yang mendalam atas pengajaran kita.

\section{Daftar Pustaka}

Arsyad, Media Pembelajaran. Jakarta: Rajawali Pers, 2014

Baley, Richard A. ed., New Testament Issues. New York: Harper adn Row, 2007.

Hamdani. Strategi Belajar Mengajar. Bandung: Pustaka Setia, 2011. 
Nainggolan, John M, Menjadi Guru Agama Kristen. Bandung: Generasi Info Media, 2007.

Nurhayati, Lusi, Psikologi Anak. Jakarta: PT Indeks, 2008.

Rusman, Model-Model Pembelajaran Mengmbangkan Profesionalisme Guru. Jakarta Raja Grafindo Persada, 2014.

Sabri, Alisuf, Psikologi Pendidikan. Jakarta: CV. Pedoman Ilmu Jaya, 2007. Sardiman. 2011. Interaksi dan Motivasi Belajar-Mengajar. Jakarta: Rajawali Pers, 2011

Sijabat, Samuel, Strategi Pendidikan Kristen. Yogjakarta:Andi, 1994.

Slameto, Belajar dan Faktor-Faktor Yang Mempengaruhinya. Jakarta: Rineka Cipta, 2010

Suprijono, Agus, Cooperative Learning. Yogyakarta: Pustaka Pelajar, 2013

Susanto, Ahmad, Teori Belajar dan Pembelajaran. Jakarta:Kencana Prenada Media Grup, 2013.

Usman, Uzer, Menjadi Guru Profesional. Jakarta: Penerbit Remaja Rosdakarya, 2006.

Winataputra, Strategi Belajar Mengajar. Jakarta: Universita Terbuka Depatemen Pendidikan Nasional, 2007. , Kamus Besar Bahasa Indonesia. Jakarta: Balai Pustaka, 2001. , Undang-Undang Republik Indonesia Nomor 20 Tahun 2003 tentang Sistem Pendidikan Nasional atau yang lebih dikenal dengan sebutan Undang-Undang Sistem Pendidikan Nasional (UUSPN), 2003. Undang-Undang Republik Indonesia Nomor 14 tahun 2005 tentang Guru dan Dosen. Jakarta: Depdiknas, 2005.

Yamin, Martinis. Strategi \& Metode dalam Model Pembelajaran. Jakarta: Referensi (GP Press Group, 2013 